\title{
Evaluation of Trichospilus diatraeae (Hymenoptera: Eulophidae) as parasitoid of the eucalyptus defoliator Euselasia eucerus (Lepidoptera: Riodinidae)
}

\author{
Bruno Zaché*, Ronelza Rodrigues da Costa Zaché, \\ Everton Pires Soliman and Carlos Frederico Wilcken \\ Sao Paulo State University (UNESP), Department of Plant Production, \\ School of Agronomic Sciences, Lageado Experimental Farm, \\ 18610-307 Botucatu, SP, Brazil
}

(Accepted 5 April 2011; First published online 13 May 2011)

\begin{abstract}
Lepidopteran pests have occurred in eucalyptus plantations in Brazil since 1948, reaching high population levels, reducing tree growth and causing considerable losses in wood production. The control of defoliating caterpillars in eucalyptus forests is complex, mainly due to the large extent of forest plantations and tree height, necessitating the aerial application of chemical or biological insecticides. Due to this complexity, alternative control methods have been proposed, for instance biological control through the use of parasitoids. Trichospilus diatraeae Cherian \& Margabandhu, 1942 is a gregarious pupal parasitoid that preferentially attacks species of the order Lepidoptera. This is the first report of T. diatraeae parasitizing pupae of the eucalyptus defoliator Euselasia eucerus Hewitson in Brazil. This parasitoid offers new perspectives for the biological control programmes of this species in eucalyptus plantations in Brazil.
\end{abstract}

Key words: Eucalyptus, forest pests, Euselasia eucerus, biological control, Trichospilus diatraeae, pupal parasitoid

\section{Introduction}

Trichospilus diatraeae Cherian \& Margabandhu, 1942 (Hymenoptera: Eulophidae) is a gregarious pupal parasitoid mainly of many Lepidoptera (Bouček, 1976). It has been recorded as a parasitoid of the families Crambidae (Cherian and Margabandhu, 1942), Noctuidae (Ètienne and Viette, 1973), Pyralidae (Ètienne and Viette, 1973; Bouček, 1976; Bennett et al., 1987), Nymphalidae (Bouček, 1976), Geometridae (Bennett et al., 1987), Pieridae (Torres-Bauza, 1994),

\footnotetext{
*E-mail: bzache@bol.com.br
}

Arctiidae (Paron and Berti-Filho, 2000) and Oecophoridae (Oliveira et al., 2005).

In 1963, T. diatraeae was imported from India to Trinidad and Tobago (Antilles) and the USA using Diatraea spp. (Lepidoptera: Crambidae) as hosts (Bennett et al., 1987). Trichospilus diatraeae was released to control pests of grasses in Senegal, with Chilo suppressalis Walker (Lepidoptera: Crambidae) as host (Bordat et al., 1977). Ėtienne and Viette (1973) and Ėtienne (1975) reported T. diatraeae in the Reunion and Mauritius Islands parasitizing the sugarcane pests Melanitis leda L. and Hedylepta indicata F. (both Lepidoptera: Crambidae), as well as 
Polydesma umbricola Boisduval (Lepidoptera: Noctuidae) and the conifer pest Trichopolydesma collutrix (Geyer) (Lepidoptera: Noctuidae). This parasitoid was used for the biological control of noctuid cotton pests in Madagascar using Ephestia kuehniella Zeller (Lepidoptera: Pyralidae) as a host for multiplication (Bournier, 1975). On the Comores Islands, Brenière et al. (1985) released T. diatraeae against the maize pest Chilo partellus Swinhoe (Lepidoptera: Crambidae). Tests with $T$. diatraeae were carried out in the USA to control the corn borer Diatraea lineolata Walker (Lepidoptera: Pyralidae) (Rodriguez-del-Bosque and Smith, 1989). Betbeder-Matibet (1990) studied the mass rearing of Chilo sacchariphagus Bojer (Lepidoptera: Crambidae) to produce $T$. diatraeae as biocontrol agent. This parasitoid was recorded in Dismorphia spio Godart (Lepidoptera: Pieridae) pupa on Inga vera (Willd.) (guaba) (Leguminosae) (Mimosoideae) in Puerto Rico (Torres-Bauza, 1994).

Lepidopteran pests can cause significant damage to eucalyptus plantations in Brazil (Zanuncio et al., 1993, 1998, 2001; Bernardino et al., 2007). Euselasia eucerus (Hewitson) (Lepidoptera: Riodinidae), also reported as Euselasia apisaon (Dalman) (Zanuncio et al., 1990; Murta et al., 2008), is a native insect to Brazil, and its caterpillars are commonly found on Eucalyptus spp. Its population grows rapidly, causing outbreaks in eucalyptus plantations in São Paulo, Rio Grande do Sul, Santa Catarina and Minas Gerais States (Zanuncio et al., 1994). The developmental cycle of E. eucerus is completed on Eucalyptus trees. The adult female lays its egg clusters on leaves. Caterpillars show gregarious behaviour and pupate on leaves (Zanuncio et al., 1990). Euselasia eucerus eggs are naturally parasitized by Trichogramma maxacalii Voegelé \& Pointel, Trichogramma demoraesi Nagaraja and Trichogramma acacioi Brun, Moraes \& Soares (all Hymenoptera: Trichogrammatidae). Its caterpillars and pupae are predated by Podisus nigrispinus
(Dallas), Brontocoris tabidus (Signoret), Supputius cincticeps (Stål) and Alcaeorrhynchus grandis (Dallas) (all Heteroptera: Pentatomidae), and the entomopathogenic fungus Paecilomyces fumosoroseus (Wize) infects its pupae (Brun et al., 1983; Oliveira et al., 2000; Murta et al., 2008). Despite having all these natural enemies, there is no specific biocontrol agent against the pupal stage used under field conditions. Currently, there is no specific mass-rearing system for Trichogramma spp. in place for control of $E$. eucerus in Brazil. The predator bugs can feed on larval and pupal stages of E. eucerus, and these species can be reared under ambient conditions. However, the number of predators produced is low considering the size of the eucalyptus plantation area in Brazil and the dispersion capacity of the pest in the field. Moreover, complementary action of different natural enemies can achieve better control levels in the field.

The objective of this study was to evaluate the impact of $T$. diatraeae as a pupal parasitoid of the eucalyptus defoliator E. eucerus as a potential alternative to chemical control of the pest.

\section{Materials and methods}

Parasitoids used in this study were originally collected on pupae of Iridopsis sp. (Lepidoptera: Geometridae) in eucalyptus plantations in Curvelo, Minas Gerais State, Brazil, in 2009. Since then thereafter, a laboratory culture has been maintained, using pupae of Thyrinteina arnobia (Stoll) (Lepidoptera: Geometridae) as hosts. Zaché et al. (2010) described the parasitoid rearing technique in detail. Euselasia eucerus eggs were collected in eucalyptus clonal plantation in Anhembi, São Paulo State (Brazil). Larvae were reared under ambient conditions on Eucalyptus urophylla S.T. Blake (Myrtaceae) leaves. Upon pupation, 15 pupae were offered to $T$. diatraeae females in a 1:1 (parasitoid:host) ratio for $72 \mathrm{~h}$. Thereafter, the
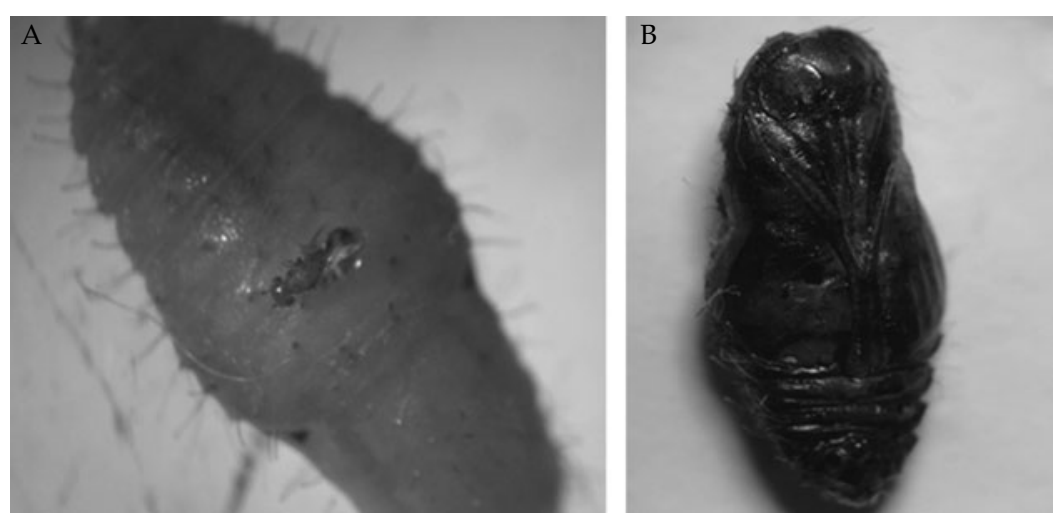

Fig. 1. A, Trichospilus diatraeae female parasitizing a Euselasia eucerus pupa; B, emergence hole of the parasitoid in a mummified pupa 
females were removed, and containers with $E$. eucerus pupae were maintained in a climatic chamber at $26 \pm 2{ }^{\circ} \mathrm{C}, 60 \pm 10 \%$ relative humidity and a $12 \mathrm{~h}$ photophase. The following parameters were determined: level of parasitism, number of emerged and not emerged parasitoids and duration of the egg-adult cycle. The pupae of E. eucerus were dissected to evaluate the non-emerged parasitoids.

\section{Results and discussion}

The level of parasitism reached $100 \%$, with an emergence rate of $86.6 \%$. A mean of $168.4( \pm 0.33$ SE) parasitoids per pupa emerged, while only 1.1 ( $\pm 0.34 \mathrm{SE}$ ) parasitoids per pupa did not emerge. The T. diatraeae egg-adult cycle was 18.4 ( $\pm 0.98 \mathrm{SE})$ days in E. eucerus pupae.

These results demonstrate for the first time, under controlled conditions, the ability of $T$. diatraeae to parasitize the pupae of E. eucerus, a species of the Riodinidae family (Fig. 1). In Brazil, the introduction of $T$. diatraeae is believed to have been accidental, and its first occurrence was recorded in 1996 on pupae of Arctiidae (Lepidoptera) in Piracicaba, São Paulo State (Paron and Berti-Filho, 2000). In 2001, the parasitoid was reported on the pupae of Cerconota anonella (Sepp) (Lepidoptera: Oecophoridae) in soursop Annona muricata L. (Annonaceae) plantations in Planaltina, Distrito Federal (Brazil) (Oliveira et al., 2001). With regard to lepidopteran forest pests in Brazil, T. diatraeae was collected from a pupa of T. arnobia on eucalyptus in Minas Gerais State (Pereira et al., 2008). In 2010, Zaché et al. reported parasitism of T. diatraeae in a pupa of the eucalyptus defoliating looper Melanolophia consimilaria (Walker) (Lepidoptera: Geometridae), a pest that pupates in the soil. More studies are needed to determine the potential of $T$. diatraeae for the biological control of lepidopteran pests in Brazilian eucalyptus plantations, as this biocontrol agent could possibly reduce the use of chemical and biological insecticides for pest control in eucalyptus.

\section{Acknowledgements}

We are grateful to the Coordenação de Aperfeiçoamento de Pessoal de Nível Superior for funding this study and Eucatex Forest Company for allowing insect pest collections in the field.

\section{References}

Bennett F. D., Glenn H., Yaseen M. and Baranowski R. M. (1987) Records of Trichospilus diatraeae, an Asian parasite (Hymenoptera: Eulophidae) from the Caribbean and Florida. Florida Entomologist 70, 184-186.
Bernardino A. S., Zanuncio T. V., Zanuncio J. C., Lima E. R. and Serrão J. E. (2007) Note on gynandromorphism in the eucalyptus defoliator Thyrinteina arnobia (Stoll, 1782) (Lepidoptera: Geometridae). Anais da Academia Brasileira de Ciência 79, 235-237.

Betbeder-Matibet M. (1990) Élevage de plusieurs espéces du genre Chilo et de certains de leurs parasites pour la lutte biologique contre les foreurs des graminees en Afrique. Insect Science and Its Application 11, 617-623.

Bordat D., Breniere J. and Coquard J. (1977) Foreurs de gramines africaines: parasitisme et techniques d'élevage. Agronomie Tropicale 32, 391-399.

Bouček Z. (1976) The African and Asiatic species of Trichospilus and Cotterellia (Hymenoptera: Eulophidae). Bulletin of Entomological Research 65, 669-681.

Bournier J. P. (1975) Sur la reproduction parthenogenetique de Trichospilus diatraeae Cher. et Margab. (Hymenoptera: Chalcidoidea). Bulletin de la Societé Entomologique de France 80, 116-118.

Brenière J., Bordat D., Vercambre B., Hamza H. and Renand M. (1985) Les opérations de lutte biologique contre lê foreur du maïs Chilo partellus (Swinhoe), Lepidoptera, dans L'île de Ngazidja. Agronomie Tropicale 40, 157-166.

Brun G. P., Moraes G. W. G. and Soares A. L. (1983) Três espécies novas de Trichogrammatidae parasitóides de lepidópteros desfolhadores de mandioca e eucalipto. Pesquisa Agropecuaria Brasileira 19, 805-810.

Cherian M. C. and Margabandhu V. (1942) A new species of Trichospilus (Hymenoptera: Chalcidoidea) from South India. Indian Journal of Entomology 4, 101-102.

Ètienne J. (1975) Notes sur l'élevage et la biologie de Pseudoperichaeta laevis (Diptera: Tachinidae) sur hote de laboratoire. Entomophaga 20, 105-111.

Ètienne J. and Viette P. (1973) Nouvelle note sur Polydesma umbricola Boisduval (Lepidoptera: Noctuidae). Bulletin de la Société Entomologique de France 78, 98-107.

Murta A. F., Ker F. T. O., Costa D. B., Espírito-Santo M. M. and Faria M. L. (2008) Efeitos de remanescentes de Mata Atlântica no controle biológico de Euselasia apisaon (Dahman) (Lepidoptera: Riodinidae) por Trichogramma maxacalii (Voegelé e Pointel) (Hymenoptera: Trichogrammatidae). Neotropical Entomology 37, 229-232.

Oliveira H. N., Zanuncio J. C., Pratissoli D. and Cruz I. (2000) Parasitism rate and viability of Trichogramma maxacalii (Hym.: Trichogrammatidae) parasitoid of the eucalyptus defoliator Euselasia apisaon (Lep.: Riodinidae), on eggs of Anagasta kuehniella (Lep.: Crambidae). Forest Ecology and Management 130, 1-6.

Oliveira H. N., Zanuncio J. C., Pedruzzi E. P. and Espindula M. C. (2005) Rearing of Thyrinteina arnobia (Lepidoptera: Geometridae) on guava and eucalyptus in the laboratory. Brazilian Archives of Biology and Technology 48, 801-806.

Paron M. R. and Berti-Filho E. (2000) Capacidade reprodutiva de Trichospilus diatraeae (Hymenoptera: Eulophidae) em pupas de diferentes hospedeiros (Lepidoptera). Scientia Agricola 57, 355-358. 
Pereira F. F., Zanuncio J. C., Tavares M. T., Pastori P. L. and Jacques G. C. (2008) Record of Trichospilus diatraeae (Hymenoptera: Eulophidae) as parasitoid of the eucalypt defoliator Thyrinteina arnobia (Lepidoptera: Geometridae) in Brazil. Phytoparasitica 36, 304-306.

Rodriguez-del-Bosque L. A. and Smith J. W. Jr (1989) Parasitization of Diatraea lineolata pupae and diapausing larvae by several exotic parasites. Florida Entomologist 72, 703-705.

Torres-Bauza J. A. (1994) Hymenopterous parasitoids of Dismorfia spio (Pieridae: Dismorphiinae). Journal of the Lepidopterists' Society 48, 266.

Zaché B., Wilcken C. F., Dacosta R. R. and Soliman E. P. (2010) Trichospilus diatraeae Cherian \& Margabandhu, 1942 (Hymenoptera: Eulophidae), a new parasitoid of Melanolophia consimilaria (Lepidoptera: Geometridae). Phytoparasitica 38, 355-357.

Zanuncio J. C., Alves J. B., Santos G. P. and Campos W. O. (1993) Levantamento e flutuação populacional de lepidópteros associados à eucaliptocultura: VI -
Região de Belo Oriente, Minas Gerais. Pesquisa Agropecuaria Brasileira 28, 1121-1127.

Zanuncio J. C., Garcia J. F., Santos G. P., Zanuncio T. V. and Nascimento E. C. (1990) Biologia e consumo foliar de lagartas de Euselasia apisaon (Dalman, 1823) (Lepidoptera: Riodinidae) em Eucalyptus spp. Revista Árvore 14, 45-54.

Zanuncio J. C., Guedes R. C. N., Zanuncio T. V. and Fabres A. S. (2001) Species richness and abundance of defoliating Lepidoptera associated with Eucalyptus grandis in Brazil and their response to plant age. Austral Ecology 26, 582-589.

Zanuncio J. C., Mezzomo J. A., Guedes R. C. N. and Oliveira A. C. (1998) Influence of strips of native vegetation on Lepidoptera associated with Eucalyptus cloeziana in Brazil. Forest Ecology and Management 108, 85-90.

Zanuncio J. C., Nascimento E. C., Garcia J. F. and Zanuncio T. V. (1994) Major lepidopterous defoliators of eucalypt in southeast Brazil. Forest Ecology and Management 65, 53-63. 